\title{
Characterization of insect galls from a vegetation area in Altinópolis, São Paulo State, Brazil
}

\author{
Amanda das Neves Ribeiro ${ }^{1,4}$; Maria Isabel Protti de Andrade Balbi ${ }^{2}$ \& Maria Virginia Urso-Guimarães ${ }^{1,3,5}$ \\ ${ }^{1}$ Universidade Federal de São Carlos (UFSCAR), Centro de Ciências Humanas e Biológicas (CCHB), Departamento de Biologia (DBio), \\ Laboratório de Sistemática de Diptera. Sorocaba, SP, Brasil. \\ 2 Universidade de São Paulo (USP), Faculdade de Filosofia, Ciências e Letras de Ribeirão Preto (FFCLRP), Departamento de Biologia, \\ Laboratório de Morfologia e Evolução de Diptera (LMED). Ribeirão Preto, SP, Brasil. ORCID: http://orcid.org/0000-0001-6092-3462. \\ E-mail: mariaisabel.balbi@gmail.com \\ ${ }^{3}$ Universidade de São Paulo (USP), Museu de Zoologia (MZUSP). São Paulo, SP, Brasil. \\ ${ }^{4}$ ORCID: http://orcid.org/0000-0002-5970-6505. E-mail:amanda_nribeiro@hotmail.com \\ ${ }^{5}$ ORCID: http://orcid.org/0000-0003-3657-9379. E-mail: mvirginiaurso@gmail.com
}

\begin{abstract}
Herein, we studied the occurrence of insect galls from natural vegetation around the Itambé Cave, Altinópolis, SP, Brazil. A sampling effort of 7.5 hours resulted in 41 gall morphotypes on 21 host plant species from 14 families. The richest families of host plants in morphotypes were Fabaceae $(N=11)$, Euphorbiaceae $(N=7)$, and Malpighiaceae $(N=5)$. Copaifera langsdorffii Desf. $(\mathrm{N}=8)$, Croton floribundus Spreng. $(\mathrm{N}=7)$, Diplopterys pubipetala (A. Juss.) W.R. Anderson \& C.C. Davis $(\mathrm{N}=5)$, and Bauhinia holophylla (Bong.) Steud. $(\mathrm{N}=4)$ were the super host plant species. Among the gall makers obtained, cecidomyiids were reared in $81 \%$ of cases and Hemiptera (Diaspididae), Hymenoptera (Eurytomidae), Coleoptera (Apion sp./ Apionidae), and Lepidoptera in $4.5 \%$ of cases, each. The parasitoids belong to the Chalcidoidea superfamily (Hymenoptera). One new species of Camptoneuromyiia (Cecidomyiidae) was found in Smilax oblongifolia Pohl ex Griseb. (Smilacaceae) as inquiline and a new species of Lestodiplosis in Diplopterys pubipetala (Malpighiaceae) was a predator. We also present the first register of Bauhinia holophylla as host plants of Cecidomyiidae. We also present the first register of Bauhinia holophylla as host plants of Cecidomyiidae, and we expand the occurrence of Rochadiplosis tibouchinae Tavares, Lopesia spinosa Maia and Couridiplosis vena Maia to São Paulo State. The results of this paper are a continuation of the description of gall morphotypes from the vegetation in Northeastern São Paulo State, and they also increase knowledge about the diversity of host plant and gall-maker associations in the Neotropical region.
\end{abstract}

Key-Words. Biodiversity; Gall maker; Neotropical region; Northeastern São Paulo State; Plant-insect interaction.

\section{INTRODUCTION}

Galls are vegetal structures produced by an abnormal increase of plant cells, tissues or organs in response to specific stimulation caused by an inductor agent, such as a virus, bacteria, nematodes or insects (Carneiro et al., 2009; Shorthouse et al., 2005; Shorthouse \& Rohfritsch, 1992). Manipulation of the host plant can be so strong that the inducer assumes control of the gall tissue's chemical composition, which is frequently quite different from the ungalled tissue (ScareliSantos, 2001). It also involves two counteracting events: the insect stresses the host organ, and the host counters it with newly differentiated tissues and new physiological activities (Raman, 2007). Some authors affirm the high level of specificity of gall maker and host plant (species-specific) associations as a result of the interaction between two genotypes (Abrahamson \& McCrea, 1986;
Abrahamson \& Weis, 1987; Stone \& Schönrogge, 2003). Galls can be induced in any vegetal organ, but the highest frequency and diversity is found in leaves (Mani, 1964). Each inducer species produces galls that are anatomically and physiologically different from those induced by other related species (Stone \& Schönrogge, 2003). In this study we describe qualitatively the insect gall morphotypes found in an area of Semideciduous Seasonal Forest in Altinópolis, which is a continuation of the description of gall morphotypes richness in the vegetation from Northeastern São Paulo State, Brazil (Saito \& Urso-Guimarães, 2012; Urso-Guimarães \& Scareli-Santos, 2006). The Semideciduous Seasonal Forest is an Atlantic Forest phytophysiognomy that is considered a priority area for conservation, due to its great biological richness and the degradation it has suffered in recent years (Martins et al., 2003). Currently, the vegetation is disturbed by anthropic action, mainly around the Itambé Cave. 


\section{MATERIAL AND METHODS}

\section{Studied area}

The samples were carried out in the Itambé Touristic Complex area, located in Altinópolis, State of São Paulo, Brazil $\left(47^{\circ} 23.0^{\prime} \mathrm{W}, 21^{\circ} 00.7^{\prime} \mathrm{S}\right.$, about $900 \mathrm{~m}$ altitude) (Fig. 1A). The Itambé Touristic Complex has an area of approximately $1.2 \mathrm{~km}^{2}$ and includes two main attractions, the Itambé Cave and the Itambé Waterfall. Altinópolis presents Cwa climate (Köppen, 1948) and the vegetation is a mosaic of Riparian Forest, Seasonal Semideciduous Forest, and Cerrado phytophysiognomies, predominated by Seasonal Semideciduous Forest (Ponzoni \& MoreiraPessôa, 2015).

\section{Sampling and analysis of the material}

Five samplings were carried out in the area from March 2000 to August 2002 (15.iii.2000, 02.viii.2000, 04.x.2000, 28.v.2001, 12.viii.2002). Each sample consisted of an hour and a half walk on a $1.5 \mathrm{~km}$ trail, with a total sampling effort of 7.5 hours. To compare the similarity of the morphotypes in the host plant species found in Altinópolis and those from other areas of São Paulo State (Luiz Antônio, Santa Rita do Passa Quatro, and Sorocaba) we performed a binary similarity analysis using the Sorensen Similarity Coefficient $(\mathrm{Ss}=2 \mathrm{a} / 2 \mathrm{a}+\mathrm{b}+\mathrm{c}$, where $a=$ total number of species in samples $A$ and $B$, $b=$ number of species present in sample $B$, but not in $A, C=$ number of species present in sample $A$, but not in B). The branches of host plants with galls were collected, photographed; some galls were dissected to obtain immature, and other galls were placed in plastic pots to rear the adult forms of gall makers and associated fauna. All insects were preserved in $70 \%$ alcohol. The cecidomyiids were later mounted on microscope slides following the methodology outlined in Gagné (1994) and identified to genera based on the keys of Gagné (1994). After identifying the cecidomyiid genus, the obtained specimens (immature and/or adults) were compared to

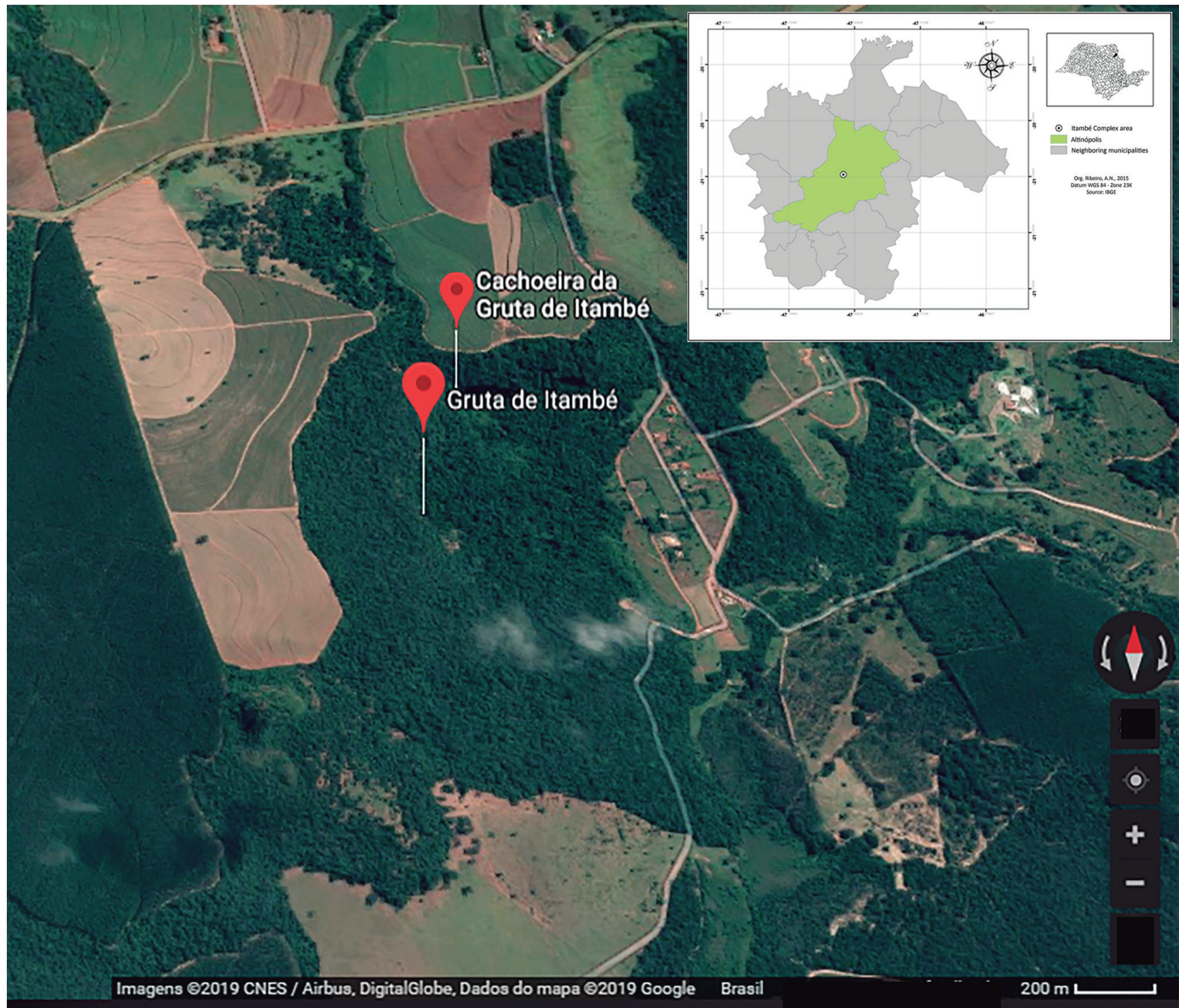

Figure 1. Aerial map of study area in Altinópolis, São Paulo State, Brazil. In the right corner, a map of Altinópolis in light green with the neighboring municipalities in grey, and in the upper right corner, Altinópolis' location in the State of São Paulo (Sources: IBGE and CNES/Airbus. Digital Globe/Google). 


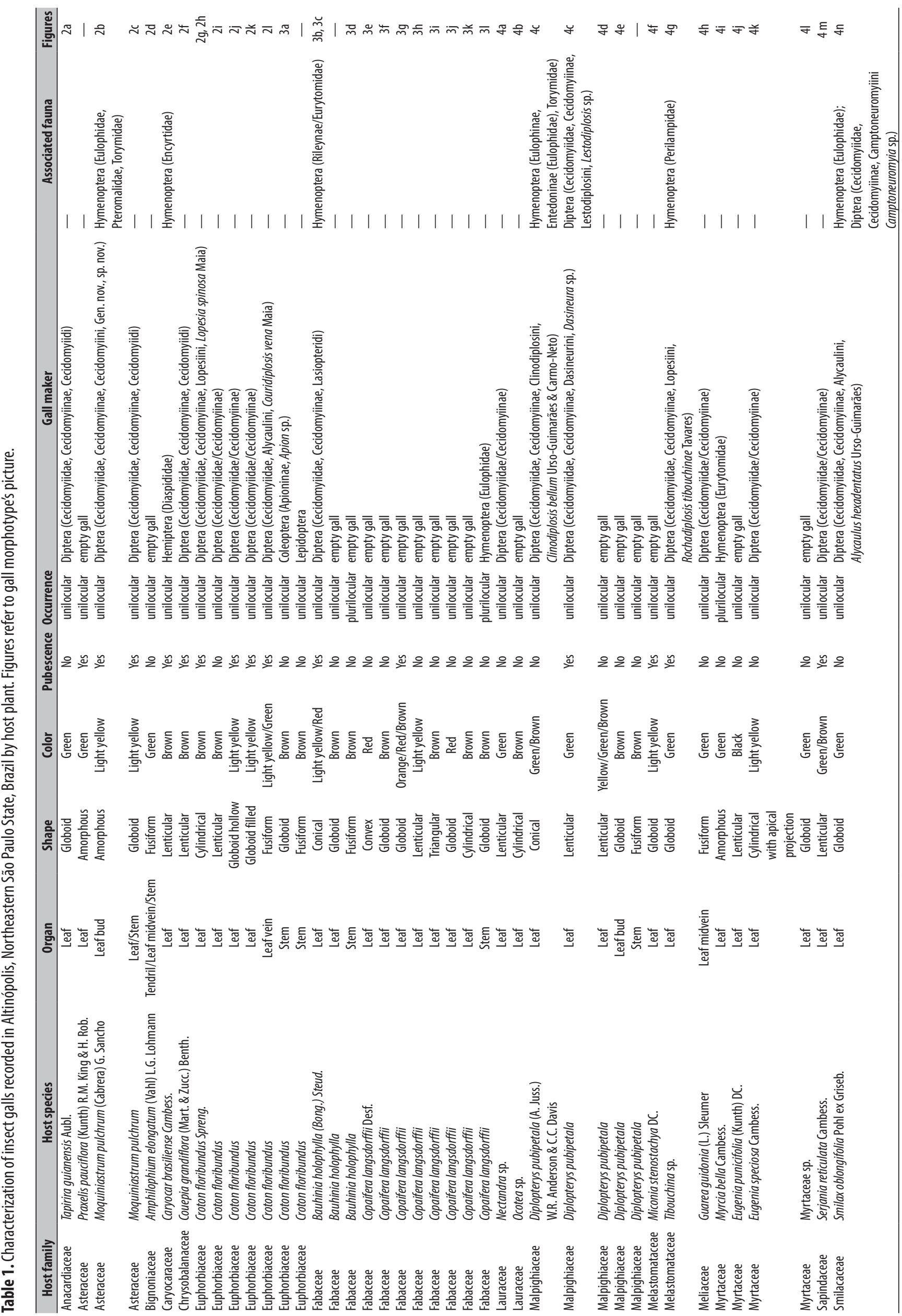


the original descriptions of Brazilian species from the genus. Other insects were sent to and identified by the specialists indicated in the acknowledgements. The nomenclature of galls follows Isaias et al. (2013). The exsiccates of host plants with fertile material are deposited in the Herbarium of FFCLRP/USP. The insects and galls are deposited in the Laboratório de Sistemática de Diptera/ UFSCar.

\section{RESULTS AND DISCUSSION}

We found forty-one gall morphotypes on 21 host plant species from 14 different families. The morphotypes were obtained mostly from leaves $(85 \%)$ followed by stems ( $15 \%)$, leaf buds (5\%), and tendrils (3\%). Our results corroborate other surveys conducted in drier environments (Mani, 1964; Maia, 2001; Urso-Guimarães et al.,
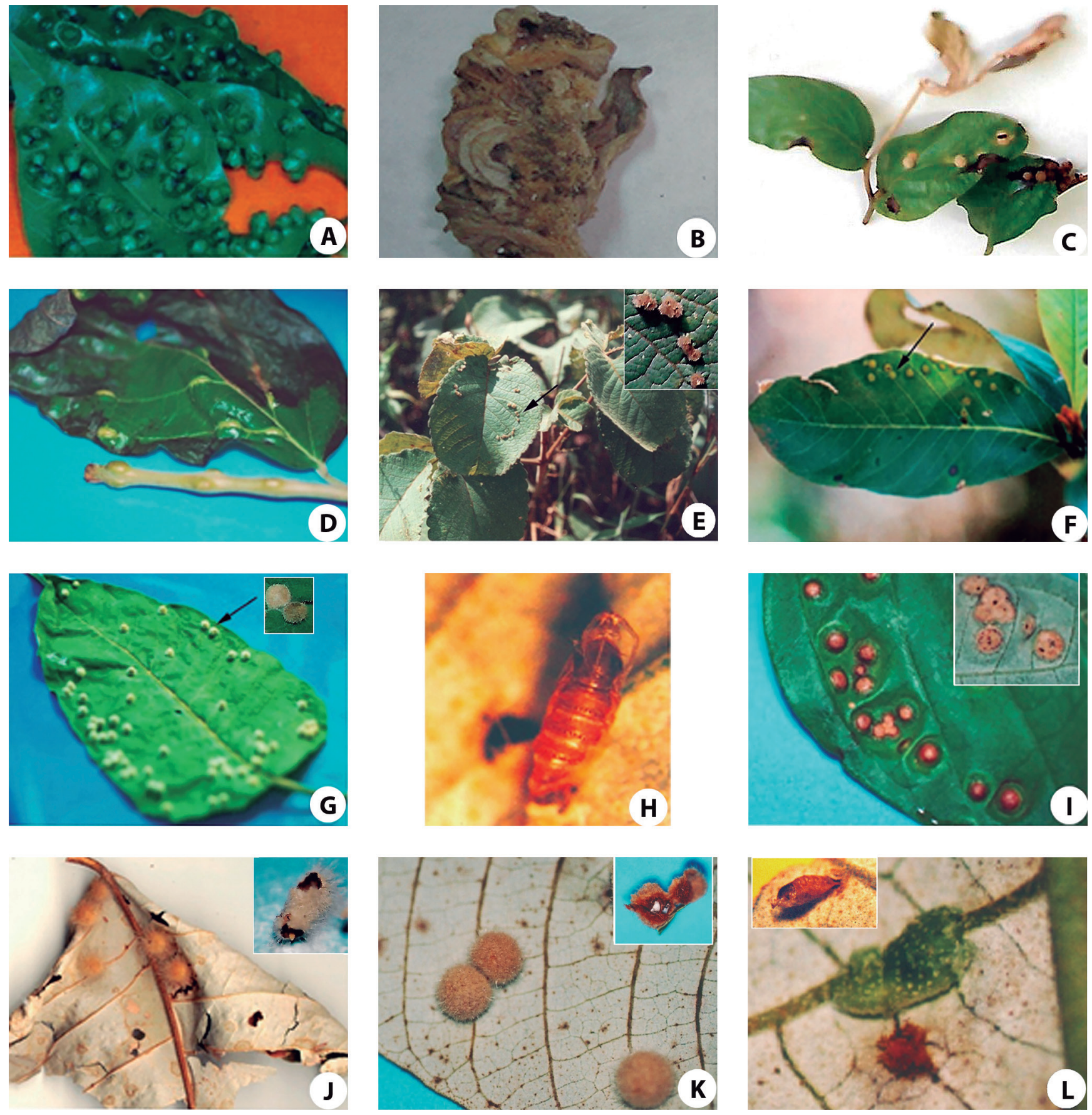

Figure 2. Gall morphotypes in host plants from Altinópolis, São Paulo State, Brazil, (A) Leaf gall of Tapirira guianensis (Anacardiaceae); (B) Bud leaf convolute in a complex gall of Moquiniastrum pulchrum (Asteraceae); (C) Leaf gall of Moquiniastrum pulchrum (Asteraceae); (D) Leaf gall of Amphilophium elongatum (Bignoniaceae), arrow on gall; (E) Leaf gall of Caryocar brasiliense (Caryocaraceae), galls in higher magnification in the upper right corner; (F) Leaf gall of Couepia grandiflora (Chrysobalanaceae), arrow on gall; (G) Cylindrical leaf gall with star trichomes of Croton floribundus (Euphorbiaceae), galls in higher magnification in the upper right corner; (H) Exuvia of Cecidomyiidae emerging from previous gall; (I) Adaxial surface of lenticular leaf gall of (roton floribundus (Euphorbiaceae), galls in abaxial surface in the upper right corner; (J) Hollow globoid leaf gall with long trichomes of (roton floribundus (Euphorbiaceae), gall opened, with a larva in higher magnification in the upper right corner; (K) Filled globoid leaf gall of (roton floribundus (Euphorbiaceae); gall opened, with fungus associated in higher magnification in the upper right corner; (L) Leaf vein gall of Croton floribundus (Euphorbiaceae), exuvia leaving the gall in the upper left corner. (Pictures: Urso-Guimarães, M.V.). 
2003; Fernandes \& Negreiros, 2006; Maia et al., 2008) including those from Northeastern São Paulo State, Brazil (Urso-Guimarães \& Scareli-Santos, 2006; Saito \& Urso-Guimarães, 2012) where the percentage of leaf galls ranges from $75 \%$ to $90 \%$. The most frequent shape of galls was globoid (37\%) followed by lenticular (25\%), fusiform (15\%), cylindrical and amorphous (7\% each), conical (5\%), and convex and triangular (2.5\% each). The most frequently sampled gall colors were brown (46\%) and green (34\%), followed by light yellow (22\%), red
(10\%), black and yellow ( $2.5 \%$ each). In relation to the indumentum and internal chambers, most galls were glabrous (64\%) and unilocular (93\%) (for detailed discussion about presence/absence of trichomes, see Saito \& Urso-Guimarães, 2012). Table 1 presents a detailed morphological description of the collected galls, and associated fauna from the samples. Plates with morphotypes are presented in Figs. 2A-L, 3A-L, 4A-N.

In descending order, gall morphotypes appeared in Fabaceae $(\mathrm{N}=11)$, followed by Euphorbiaceae $(\mathrm{N}=7)$,
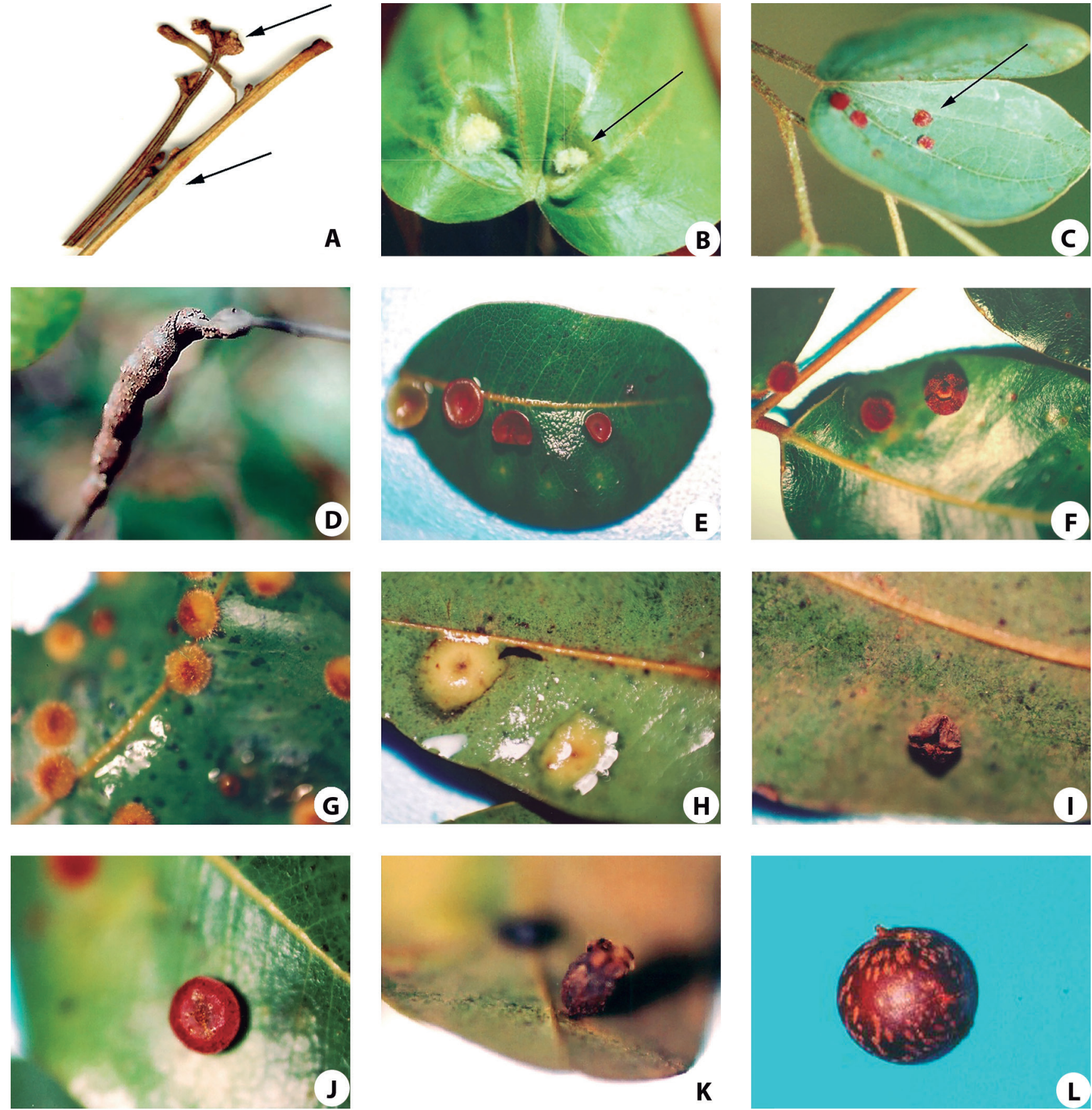

Figure 3. Gall morphotypes in host plants from Altinópolis, São Paulo State, Brazil. (A) Globoid and fusiform stem galls of Croton floribundus (Euphorbiaceae), arrow on both galls; (B) Immature leaf gall of Bauhinia holophylla (Fabaceae), arrow on gall; (C) Mature leaf gall of Bauhinia holophylla (Fabaceae), arrow on gall; (D) Stem gall of Bauhinia holophylla (Fabaceae); (E) Convex leaf gall of Copaifera langsdorffii (Fabaceae); (F) Globoid glabrous leaf gall of Copaifera langsdorffii (Fabaceae); (G) Globoid leaf gall with red and orange trichomes of Copaifera langsdorffii (Fabaceae); (H) Lenticular leaf gall of Copaifera langsdorffii (Fabaceae); (I) Triangular leaf gall of Copaifera langsdorffii (Fabaceae); (J) Globoid red leaf gall of Copaifera langsdorffii (Fabaceae); (K) Cylindrical leaf gall of Copaifera langsdorffii (Fabaceae); (L) Globoid stem gall of Copaifera langsdorffii (Fabaceae). (Pictures: Urso-Guimarães, M.V.). 

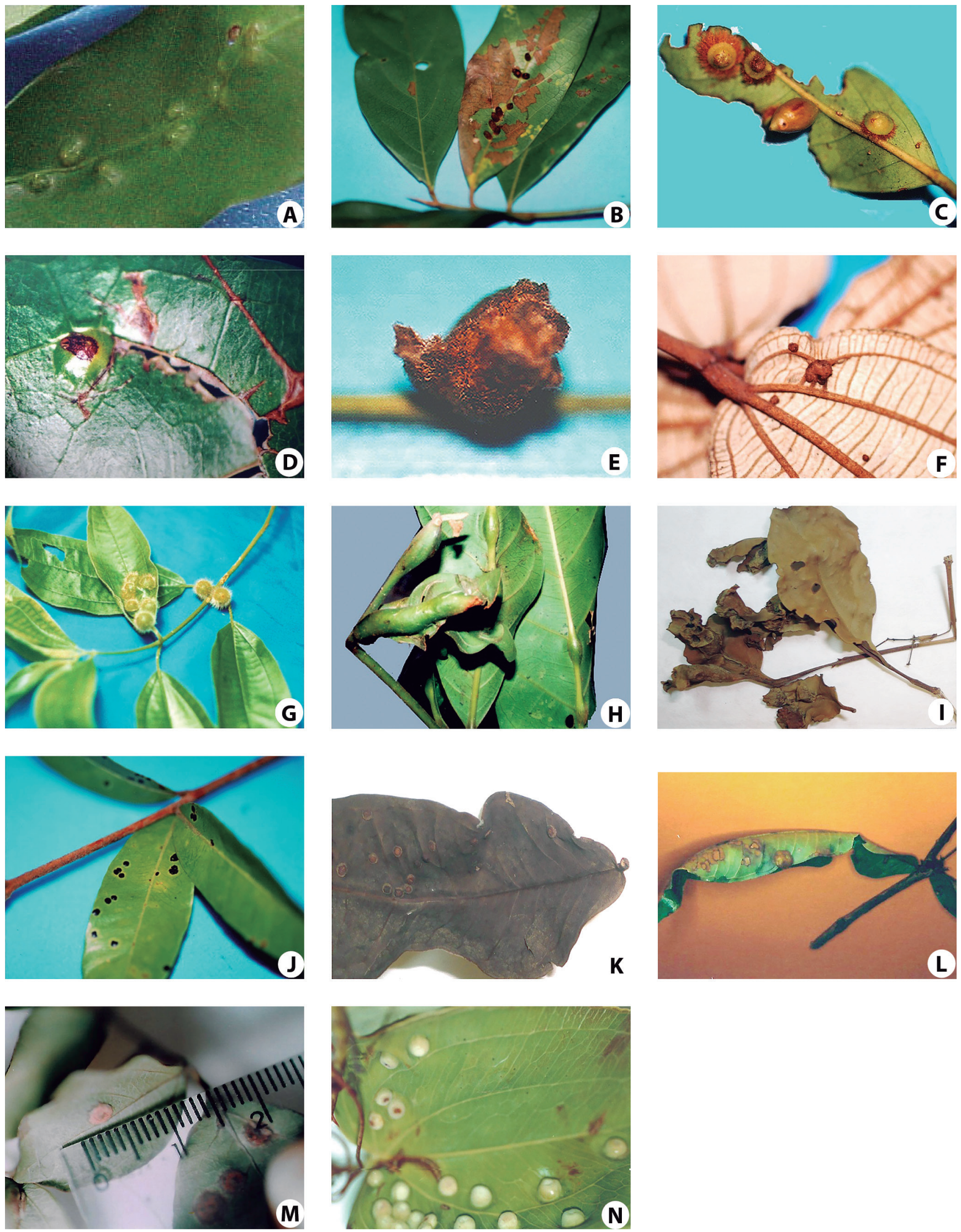

Figure 4. Gall morphotypes in host plants from Altinópolis, São Paulo State, Brazil. (A) Leaf gall of Nectandra sp. (Lauraceae); (B) Leaf gall Ocotea sp. (Lauraceae); (C) Cylindrical and lenticular hairy leaf galls of Diplopterys pubipetala (Malpighiaceae); (D) Lenticular leaf gall of Diplopterys pubipetala (Malpighiaceae); (E) Bud leaf gall of Diplopterys pubipetala (Malpighiaceae); (F) Leaf gall of Miconia stenostachya (Melastomataceae); (G) Leaf hairy gall of Tibouchina sp. (Melastomataceae); (H) Leaf gall of Guarea guidonea (Meliaceae); (I) Leaf gall of Myrcia bella (Myrtaceae); (J) Leaf gall of Eugenia punicifolia (Myrtaceae), arrow on gall; (K) Leaf gall of Eugenia speciosa (Myrtaceae), arrow on gall; (L) Leaf gall of Myrtaceae sp., arrow on gall; (M) Leaf gall of Serjania reticulata (Sapindaceae); (N) Leaf gall of Smilax oblongifolia (Smilacaceae). (Pictures: Urso-Guimarães, M.V.). 
Malpighiaceae $(\mathrm{N}=5)$, Myrtaceae $(\mathrm{N}=4)$, Asteraceae $(\mathrm{N}=3)$, Lauraceae and Melastomataceae $(\mathrm{N}=2)$. Information about morphotype richness of other families and species is given in Table 2. Our results indicated that the richer the host family, the richer their gall morphotypes, corroborating data previously obtained in the Neotropical region (Gagné, 1994; Araújo, 2011; Santana \& Isaias, 2014). However, it's important to highlight that of the 41 morphotypes sampled, 23 were found in the four host plant species: Copaifera langsdorffii, Croton floribundus, Diplopterys pubipetalum, and Bauhinia holophylla, with eight, seven, five and three morphotypes, respectively. Plants are referred to as super host plants when a single species presents a high number of different gall morphotypes caused by distinct inducers (Veldtman \& McGeoch, 2003) and also increases the number of morphotypes per family as related by Araújo (2011).

Prior to this study, only four surveys have been performed in areas with Seasonal Semideciduous Forest (SSF):, Maringá/PR (Carvalho et al., 2015), Goiânia/GO (Santos et al., 2010), Serra da Bodoquena/MS (UrsoGuimarães et al., 2017), and Sorocaba/SP (Ansaloni et al., 2018), which were compared to Altinópolis (this study). Table 3 shows the compared richness of gall morphotypes in these areas, as well as from nearby areas of Cerrado vegetation from Northeastern São Paulo State. The average 1.95 morphotypes per plant species in

Table 2. Richness of gall morphotypes in plant host family and species from vegetation around Itambé Cave, Altinópolis, São Paulo State, Brazil.

\begin{tabular}{lcc}
\hline $\begin{array}{c}\text { Host Plant Families } \\
(\mathbf{N}=\mathbf{1 4})\end{array}$ & $\begin{array}{c}\text { Number of species } \\
(\mathbf{N}=\mathbf{2 1})\end{array}$ & $\begin{array}{c}\text { Gall Morphotypes } \\
(\mathbf{N}=\mathbf{4 1})\end{array}$ \\
\hline Fabaceae & 2 & 11 \\
Euphorbiaceae & 1 & 7 \\
Malpighiaceae & 1 & 5 \\
Myrtaceae & 4 & 4 \\
Asteraceae & 2 & 3 \\
Lauraceae & 2 & 2 \\
Melastomataceae & 2 & 2 \\
Anacardiaceae & 1 & 1 \\
Bignoniaceae & 1 & 1 \\
Caryocaraceae & 1 & 1 \\
Chrysobalanaceae & 1 & 1 \\
Meliaceae & 1 & 1 \\
Sapindaceae & 1 & 1 \\
Smilacaceae & 1 & 1 \\
\hline
\end{tabular}

Altinópolis is comparable to the average found in other dry environments (see also Table 3 in Urso-Guimarães et al., 2017) and is higher than those found in areas with the same vegetation in Goiânia/GO (1.7), Serra da Bodoquena/MS (1.6), and Maringá/PR (1.2). This average is only comparable to the Seasonal Semideciduous Forest area in Sorocaba in Southeastern São Paulo State (2.1), where the sampling effort was 48 hours and it is higher than the Cerrado areas in Luiz Antônio (1.7) and Santa Rita do Passa Quatro (1.4), both nearby areas in the State of São Paulo.

Comparing morphotypes of the host plant species found in Altinópolis with those from other areas, we found low similarity among them, with the Sorensen Coefficient (Ss) varying from 0.01 to 0.28 (Table 4). The highest similarity was found between Altinópolis (SSF) and Santa Rita do Passa Quatro (Cerrado Pé-de-Gigante) with $\mathrm{Ss}=0.28$, even though they have different phytophysiognomies and are not the closest areas $(122 \mathrm{~km})$. Two factors influenced such result, the first was the presence of eleven similar gall morphotypes in eight host plant species with wide distribution, which are Amphilophium elongatum (Vahl) L.G. Lohmann, Caryocar brasiliense Cambess, Copaifera langsdorffii Desf., Diplopterys pubipetala (A. Juss.) W.R. Anderson \& C.C. Davis, Miconia stenostachya DC., Moquiniastrum pulchrum (Cabrera) G. Sancho, Myrcia bella Cambess, and Tapirira guianensis Aubl.; the second factor was the presence of three super host plant species, Copaifera langsdorffii, Diplopterys pubipetala, and Moquiniastrum pulchrum, responsible for six of the eleven similar gall morphotypes.

Of the associated gall fauna from Altinópolis, we recorded eighteen species of Diptera (Cecidomyiidae) (81.8\%), two species of Hymenoptera (Eulophidae and Eurytomidae) (9.1\%), and one species of Hemiptera

Table 4. Sorensen Similarity Coefficient (Ss) comparing Altinópolis gall morphotypes per host plant species from Semideciduous Seasonal Forest (SSF) in the States of Mato Grosso do Sul and Southeastern São Paulo and with Cerrado in Northeastern São Paulo State.

\begin{tabular}{lc}
\hline \multicolumn{1}{c}{ Locality } & Ss \\
\hline Altinópolis X Santa Rita do Passa Quatro (Urso-Guimarães \& Scareli-Santos, 2006) & 0,28 \\
Altinópolis X Sorocaba (Ansaloni et al., 2018) & 0,15 \\
Altinópolis X Luiz Antônio (Saito \& Urso-Guimarães, 2012) & 0,10 \\
Altinópolis X Serra da Bodoquena, MS (Urso-Guimarães et al., 2017) & 0,01 \\
\hline
\end{tabular}

Table 3. Richness of gall morphotypes from localities with Seasonal Semideciduous Forest and Cerrado phytophysiognomies in Northeastern São Paulo State.

\begin{tabular}{|c|c|c|c|c|}
\hline Locality & $\begin{array}{c}\text { Richness of gall } \\
\text { morphotypes }\end{array}$ & $\begin{array}{c}\text { Richness of host plant } \\
\text { species }\end{array}$ & $\begin{array}{c}\text { Average number of gall/host } \\
\text { plant species }\end{array}$ & $\begin{array}{c}\text { Total sampling } \\
\text { effort }\end{array}$ \\
\hline Sorocaba, SP (Ansaloni et al., 2018) & 113 & 54 & 2.1 & $48 \mathrm{~h}$ \\
\hline Altinópolis, SP (this study) & 41 & 21 & 1.95 & $7.5 \mathrm{~h}$ \\
\hline Estação Ecológica do Jataí, Luiz Antônio, SP (Saito \& Urso-Guimarães, 2012) & 69 & 41 & 1.7 & $15 \mathrm{~h}$ \\
\hline Goiás, G0 (Santos et al., 2010) & 34 & 20 & 1.7 & not informed \\
\hline Serra da Bodoquena, MS (Urso-Guimarães et al., 2017) & 65 & 39 & 1.6 & $2 \mathrm{~h}$ \\
\hline Santa Rita do Passa Quatro, SP (Urso-Guimarães \& Scareli-Santos, 2006) & 35 & 25 & 1.4 & not informed \\
\hline Maringá, PR (Carvalho et al., 2015)* & 40 & 35 & 1.2 & not informed \\
\hline
\end{tabular}

* In Carvalho et al., 2015 were not identified all morphospecies and morphotypes are not characterized, even so we chose to include these data because it is one of the few works in the area of Seasonal Semideciduous Forest phytophysiognomy. 
(Diaspididae), Coleoptera (Apion sp./Apionidae) and Lepidoptera (4.5\% each).

Of the eighteen species of cecidomyiids found, five species were known: Rochadiplosis tibouchinae Tavares associated with Tibouchina sp. (Tavares, 1917) from Rio de Janeiro State (Tavares, 1917), and Lopesia spinosa Maia and Couridiplosis vena Maia associated with Croton floribundus (Euphorbiaceae) from Minas Gerais State (Maia \& Fernandes, 2004), and Clinodiplosis bellum UrsoGuimarães and Carmo-Neto found in conical leaf galls of Diplopterys pubipetala (Urso-Guimarães \& Carmo-Neto, 2015) and Alycaulus hexadentatus found on leaf galls in Smilax oblongifolia Pohl ex Grisebach (Smilacaceae) in Altinópolis/São Paulo State (Urso-Guimarães, 2018). The other thirteen species of Cecidomyiidae (78\%) are probably new species, four of which are going to be described in other papers, as well as the previously unknown larvae of $L$. spinosa. L. spinosa and C. vena associated with C. floribundus (Euphorbiaceae) are registered in the São Paulo State for the first time.

Parasitoids were found in $15 \%$ of the sampled galls (Table 1) and belong to Hymenptera families Encyrtidae, Eulophidae (Entedoninae, Eulophinae), Eurytomidae (Rileynae), Pteromalidae, Perilampidae, and Torymidae. When compared to other environments as the Cerrado in Minas Gerais State (34\%, Maia \& Fernandes, 2004), Restinga in São Paulo State (24\%, Maia et al., 2008), and especially the Restinga in Rio de Janeiro State (95\%, Maia \& Azevedo, 2009) such result is relatively low.

Herein, Bauhinia holophylla (Bong.) Steud is registered as host plant of Cecidomyiidae for the first time. The results of this work help increase knowledge about the diversity of the host plant and gall-maker associations in the Neotropical region, which, despite researchers' efforts, still presents large information gaps.

\section{ACKNOWLEDGMENTS}

The authors thank Dr. Dalton de Souza Amorim (FFCLRP/USP) for infrastructure support and identification of the Diaspididae (Hemiptera), Dr. Helena Carolina Onody for identification of the Chalcidoidea (Hymenoptera), Dr. Alessandra Tomaselli Fidélis (UNESP/Rio Claro), Dr. Ana Carolina Bonifácio Caboni (ICMBio), Dr. Olga Kotchetkoff-Henriques (PMRP), and Dr. Ricardo Barosela (FFCLRP/USP) for identification of botanical species,. This study was supported by FAPESP (Proc. \#99/01429-1).

\section{REFERENCES}

Abrahamson, W.G. \& McCrea, K.D. 1986. The impacts of galls and gall makers on plants. Proceedings of Entomoogic Society of Washington, 88(2): 364-367.

Abrahamson, W.G. \& Weis, A.E. 1987. Nutritional ecology of arthropod gall makers. In: Slansky-Junior, F. \& Rodriquez, J.G. (Eds.). Nutritional ecology of insects, mites, spiders, and related invertebrates. New York, John Wiley \& Sons. p. 235-258.
Ansaloni, L.S.; Salmazo, J.R. \& Guimarães, M.V.U. 2018. Entomogen galls in a Seasonal Semideciduous Forest area in Sorocaba, Southeast of São Paulo State, Brazil. Biota Neotropica, 18(4): e20180523. Avaiable in: http://doi. org/10.1590/1676-0611-bn-2018-0523. Access in: 17/12/2018.

Araújo, W.S. 2011. Can host plant richness be used as a surrogate for galling insect diversity? Tropical Conservation Science, 4(4): 420-427.

Carneiro, M.A.A.; Branco, C.S.A.; Braga, C.E.D.; Almada, E.D.; Costa, M.B.M.; Maia, V.C. \& Fernandes, G.W. 2009. Are gall midge species (Diptera, (ecidomyiidae) host-plant specialists? Revista Brasileira de Entomologia, 53: 365-378.

Carvalho, L.L.G.; Santos, R.N.S. \& Barbosa, J.S. 2015. Ocorrência de galhas entomógenas em plantas do Parque Florestal dos Pioneiros, em Maringá, Paraná, Brasil. Revista Uningá, 23(1): 21-23.

Fernandes, G.W. \& Negreiros, D. 2006. A comunidade de insetos galhadores da RPPN Fazenda Bulcão, Aimorés, Minas Gerais, Brasil. Lundiana, 7(2): 111-120.

Gagné, R.J. 1994. The gall midges of the Neotropical Region. Ithaca, Commstock Publ. 352p.

Isaias, R.M.S.; Carneiro, R.G.S.; Oliveira, D.C. \& Santos, J.C. 2013. Illustrated and Annotated Checklist of Brazilian Gall Morphotypes. Neotropical Entomology, 42: 230-239.

Köppen, W. 1948. Climatologia: con un estudio de los climas de la tierra. México, D.F., Fondo de Cultura Econômica. 479p.

Maia, V.C. 2001. The gall midges (Diptera, Cecidomyiidae) from three restingas of Rio de Janeiro State, Brazil. Revista Brasileira de Zoologia, 18(2): 583-629.

Maia, V.C. \& Azevedo, M.A.P. 2009. Micro-himenópteros associados com galhas de Cecidomyiidae (Diptera) em Restingas do Estado do Rio de Janeiro (Brasil). Biota Neotropica, 9(2): 151-164. Available in: http:// www.scielo.br/pdf/bn/v9n2/a15v09n2.pdf. Access in: 17/12/2018.

Maia, V.C. \& Fernandes, G.W. 2004. Insect galls from Serra de São José (Tiradentes, MG, Brazil). Brazilian Journal of Biology, 64(3a): 423-445.

Maia, V.C.; Magenta, M.A. \& Martins, S.E. 2008. Ocorrência e caracterização de galhas de insetos em áreas de restinga de Bertioga (São Paulo, Brasil). Biota Neotropica, 8(1): 167-197. Avaiable in: http://www.scielo.br/pdf/ bn/v8n1/a20v8n1.pdf. Access in: 17/12/2018.

Mani, M.S. 1964. Ecology of plant galls. The Netherlands, The Hague Dr. W. Junk Publishers.

Martins, S.V.; Silva, N.R.S.; Souza, A.L. \& Neto, J.A.A. 2003. Distribuição de espécies arbóreas em um gradiente topográfico de Floresta Estacional Semidecidual em Viçosa, MG. Scientia Florestalis, 64: 172-181.

Ponzoni, F.J. \& Moreira-Pessôa, A.C. 2015. Análise temporal da ação antrópica sobre diferentes fitofisionomias da Mata Atlântica nos estados de São Paulo e Rio de Janeiro. In: Simpósio Brasileiro de Sensoriamento Remoto, 170. Anais. João Pessoa, SBSR/INPE.

Raman, A. 2007. Insect-induced plant galls of India: unresolved questions. Current Science, 92: 748-757.

Saito, V.S. \& Urso-Guimarães, M.V. 2012. Characterization of galls, insect galls andassociated fauna of Ecological Station of Jataí (Luiz Antônio, SP). Biota Neotropica, 12: 99-107.

Santana, A.P. \& Isaias, R.M.S. 2014. Galling insects are bioindicators of environmental quality in a Conservation Unit. Acta Botanica Brasilica, 28(4): 594-608.

Santos, B.B.; Ferreira, H.D. \& Araújo, W.S. 2010. Ocorrência e caracterização de galhas entomógenas em uma área de Floresta Estacional Semidecídua em Goiânia, Goiás, Brasil. Acta Botanica Brasilica, 24(1): 243-249.

Scareli-Santos, C. 2001. Avaliação de sistema galhador-planta hospedeira em ambiente de cerrado: aspectos morfo-anatômicos e fitoquímicos. Tese (Doutorado em Ciências). São Carlos, Universidade Federal de São Carlos - UFSCar. 
Shorthouse, J.D. \& Rohfritsch, 0. 1992. Biology of Insect induced Galls. Oxford, $0 x f o r d$ University Press.

Shorthouse, J.D.; Wool, D. \& Raman, A. 2005. Gall-inducing insects - Nature's most sophisticated herbivores. Basic and Applied Ecology, 6: 407-411.

Stone, G.N. \& Schönrogge, K. 2003. The adaptive significance of insect gall morphology. Trends Ecology and Evolution, 18: 512-522.

Tavares, J.S. 1917. As cecídias do Brazil que se criam nas plantas da família das Melastomataceae. Brotéria, Série Zoologica, 15: 18-49, pls. I-V.

Urso-Guimarães, M.V. 2018. Two New Species of the Tribe Alycaulini (Diptera: Cecidomyiidae) from Brazil. Florida Entomologist, 101(4): 603-611. https://bioone.org/accountAjax/Download?fullDOI=10.1653\%2F024.1 01.0422\&downloadType $=$ journal\%20article\&D0I $=10.1653 \% 2 \mathrm{~F} 024.10$ 1.0422\&isResultClick=True. Access in: 29/01/2019.

Urso-Guimarães, M.V. \& Carmo-Neto, A.M. 2015. A new species of gall midge associated with Diplopterys pubipetala (A. Juss.) Anderson and Davis
(Malpighiaceae) from Altinópolis, São Paulo, Brazil. Brazilian Journal of Biology, 75(1): 175-179.

Urso-Guimarães, M.V. \& Scareli-Santos, C. 2006. Galls and Gall makers in plants from the Pé-de-Gigante Cerrado Reserve, Santa Rita do Passa Quatro, SP, Brazil. Brazilian Journal of Biology, 66(1b): 357-369.

Urso-Guimarães, M.V.; Castelo, A.C.D.; Kataoka, E. \& Koch, I. 2017. Characterization of entomogen galls from Mato Grosso do Sul, Brazil. Revista Brasileira de Entomologia, 61(1): 25-42.

Urso-Guimarães, M.V.; Scareli-Santos, C. \& Bonifácio-Silva, A.C. 2003. Occurrrence and characterization of entomogen galls in plants from natural vegetation areas in Delfinópolis, MG, Brazil. Brazilian Journal of Biology, 63(4): 705-715.

Veldtman, R. \& M.A. McGeoch. 2003. Gall-forming insect species richness along a non-scleromorphic vegetation rainfall gradient in South Africa: the importance of plant community composition. Austral Ecology, 28: 1-13. 